\title{
The medium is the messenger
}

Knutton S, Rosenshine I, Pallen MJ, et al. A novel EspA-associated surface organelle of enteropathogenic Escherichia coli involved in protein translocation into epithelial cells. EMBO f 1998;17:2166-76.

\section{Abstract}

Enteropathogenic Escherichia coli (EPEC), like many bacterial pathogens, employ a type III secretion system to deliver effector proteins across the bacterial cell. In EPEC, four proteins are known to be exported by a type III secretion system-EspA, EspB and EspD required for subversion of host cell signal transduction pathways and a translocated intimin receptor (Tir) protein (formerly Hp90) which is tyrosinephosphorylated following transfer to the host cell to become a receptor for intimin-mediated intimate attachment and 'attaching and effacing' (A/E) lesion formation. The structural basis for protein translocation has yet to be fully elucidated for any type III secretion system. Here, we describe a novel EspA-containing filamentous organelle that is present on the bacterial surface during the early stage of $\mathrm{A} / \mathrm{E}$ lesion formation, forms a physical bridge between the bacterium and the infected eukaryotic cell surface and is required for the translocation of EspB into infected epithelial cells.

\section{Comment}

Enteropathogenic Escherichia coli (EPEC) is an important category of diarrhoeagenic bacteria causing acute and chronic diarrhoea in young children in both developing and developed countries, and sporadic cases in adults. ${ }^{1}$ There has been rapid recent progress in understanding the early stages of EPEC pathogenesis and the events involved in the formation of the characteristic attaching-effacing (A/E) lesion, ${ }^{23}$ where EPEC attach to the mucosal surface and transform finger-like microvilli into a pedestal-like structure with which the bacterium makes intimate contact. ${ }^{45}$ The main reasons for this progress are the availability of in vitro cell culture models which reproduce the lesion, ${ }^{6}$ the ability to recognise easily the lesion by fluorescence and electron microscopy, ${ }^{7}$ and the existence of the "virtual" EPEC laboratory spanning several continents, where researchers from different institutes have shown a ready willingness to exchange ideas, bacterial strains and expertise. Just such a co-operative paper has been published by Knutton and colleagues, encompassing the UK, Israel and South America (with assistance from the USA). However, before commenting on the paper it is important to put it in the context of the rapidly changing field of EPEC research.

The genes needed for $\mathrm{A} / \mathrm{E}$ lesion formation have been identified using in vitro cell culture models of virulence and we are now entering the exciting period where the functions of the various genes are teased out. The EPEC chromosome contains a pathogenicity island-the locus of enterocyte effacement (LEE) - which contains the genes necessary and sufficient for $\mathrm{A} / \mathrm{E}$ lesion formation. ${ }^{8}$ The LEE is divided into three regions, (1) comprising genes for a type III secretion system, (2) containing eae and tir (or espE) $)^{9}$ genes, and (3) encoding EPEC secreted proteins (EspA, D and B). ${ }^{10}$ The eae gene encodes intimin, a $94 \mathrm{kDa}$ outer membrane protein which mediates intimate binding of EPEC to the host. ${ }^{11} \mathrm{Tir} / \mathrm{EspE}$ is a novel secreted protein which enters the host cell to form the receptor for intimin. Thus a startling recent observation has been that EPEC provides its own receptor. ${ }^{12} \mathrm{EspB}$ is also translocated into the host cell ${ }^{13}$ and EspB, EspA and EspD are all necessary for $\mathrm{A} / \mathrm{E}$ lesion formation. Interesting questions being asked included how does EPEC make initial contact with the host cell, and how are Tir and EspB delivered? It had been suggested from cell culture work that the bundle forming pilus (BFP), encoded by genes on a virulence plasmid, was responsible for non-intimate, initial attachment. ${ }^{14}$ However, organ culture of human intestine with EPEC lacking $\mathrm{BFP}$ expression still showed $\mathrm{A} / \mathrm{E}$ lesion formation and provided evidence that $\mathrm{BFP}$ is responsible for interbacterial attachment and complex colony formation after $\mathrm{A} / \mathrm{E}$ lesion formation - that is, for later rather than earlier events. ${ }^{15}$

The recent paper by Knutton and colleagues has now provided the modus operandi for initial attachment and EPEC protein delivery into the host cell with the finding that the EPEC secreted protein, EspA, is not a signalling protein but is a structural protein and is the main component of an attachment/delivery system (fig 1). This elegant and beautifully illustrated paper reports that EspA forms long, hollow, tubes which are (1) produced prior to contact with the host, (2) bridge the bacterium and the host to achieve non-intimate adhesion, and (3) are lost after $\mathrm{A} / \mathrm{E}$ lesion formation. Without EspA, neither EspB or Tir are translocated, the implication being that these two secreted proteins pass into the host via the EspA structure. Some uncertainties remain-EPEC mutant strains lacking EspD produce short EspA filaments suggesting that the attachment/delivery structure is a complex of two, or more, EPEC proteins. EspA structures only form weak attachments to the host, indeed they were only detected by weak washing of experimental preparations, raising questions concerning the involvement of other, as yet unidentified, adhesin(s) in initial non-intimate binding to the host.

EspA in EPEC is the first example of how cell contact and translocation is achieved in a type III system, and disruption of this system should interrupt the pathogenic process. This is of broad and specific relevance as type III secretion systems are conserved, ${ }^{16}$ are common to many Gram negative pathogens of the plant and animal kingdoms, and are responsible for the secretion and translocation of virulence factors in other human gastrointestinal bacterial pathogens. Different proteins are secreted in the various bacterial species-outer membrane proteins (Yop) by yersinia, ${ }^{17}$ inner and outer membrane proteins by salmonella (Sip and Sop respectively), ${ }^{18} 19$ and invasion plasmid antigens (Ipa) by shigella. ${ }^{20}$ Similar 
EPEC and proteins involved

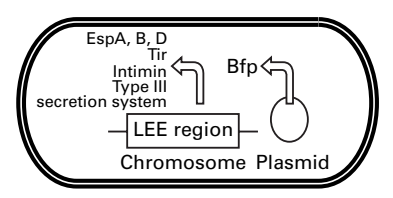

Initial contact

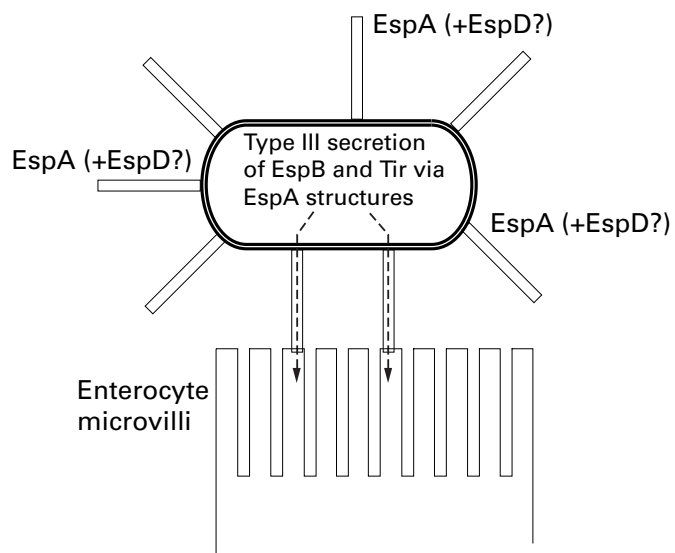

Attaching-effacing

lesion

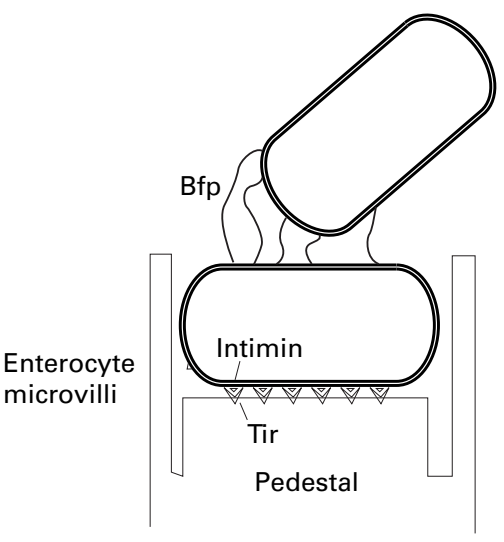

Figure 1 Diagram of the EPEC attaching-effacing lesion showing the proteins involved. EspA delivery of Tir and EspB, and pedestal formation.

ephemeral surface appendages (termed invasomes) have been described in salmonella ${ }^{21}$ which could fulfil an equivalent function to EspA, although host contact is required for their production and they are very short lived.

Knutton et al's paper also strengthens the concept of cross-talk between the host and microorganism. EspA structures are lost as $\mathrm{A} / \mathrm{E}$ lesions form, suggesting some host-bacterium interchange alters bacterial gene expression. Indeed, EPEC pathogenesis seems to involve a carefully orchestrated cascade of events involving bacterial gene activation and suppression which is globally regulated by a plasmid encoded regulatory system (Per). ${ }^{1}$

Finally, in common with many papers on bacterial pathogenesis, the evidence in this paper emanates from in vitro cell culture work. The challenge which faces workers in the field is to determine whether in vitro fully reflects in vivo.

\section{A D PHILLIPS}

University Department of Paediatric Gastroenterology, Royal Free Hospital, Pond Street, London NW3 2QG, UK

1 Nataro JP, Kaper JB. Diarrheagenic Escherichia coli. Clin Microbiol Rev 1998;11:141-201.

2 Donnenberg MS, Kaper JB, Finlay BB. Interactions between Eschericia coli and host epithelial cells. Trends Microbiol 1997;5:109-14.

3 Kaper JB. EPEC delivers the goods. Trends Microbiol 1998;6:169-73.

4 Ulshen MH, Rollo JL. Pathogenesis of Escherichia coli gastroenteritis in man - another mechanism. N Engl f Med 1980;302:99-101.

5 Moon HW, Whipp SC, Argenzio RA, et al. Attaching and effacing activities of rabbit and human enteropathogenic Escherichia coli in pig and rabbit intestines. Infect Immun 1983;41:1340-51.

6 Cravioto A, Gross RJ, Scotland SM, et al. An adhesive factor found in strains of Escherichia coli belonging to the traditional infantile enteropathogenic serotypes. Curr Microbiol 1979;3:95-9.
7 Knutton S, Baldwin T, Williams PH, et al. Actin accumulation at sites of bacterial adhesion to tissue culture cells: basis of a new diagnostic test for enteropathogenic and enterohemorrhagic Escherichia coli. Infect Immun 1989;57:1290-8.

8 McDaniel TK, Kaper JB. A cloned pathogenicity island from enteropathogenic Escherichia coli confers the attaching-effacing phenotype on E coli K12. Mol Microbiol 1997;23:399-407.

9 Deibel C, Kramer S, Chakraborty T, et al. EspE, a novel secreted protein of attaching effacing bacteria, is directly translocated into infected host cells, where it appears as a tyrosine-phosphorylated $90 \mathrm{kDa}$ protein. Mol Microbiol 1998;28:463-74.

10 Elliott SJ, Wainwright LA, McDaniel TK, et al. The complete sequence of the locus of enterocyte effacement (LEE) from enteropathogenic Escherichia coli E2348/69. Mol Microbiol 1998;28:1-4.

11 Jerse $\mathrm{AE}, \mathrm{Yu} \mathrm{J}$, Tall $\mathrm{BD}$, et al. A genetic locus of enteropathogenic Escherichia coli necessary for the production of attaching effacing lesions oil tissue culture cells. Proc Natl Acad Sci USA 1990;87:2842-4.

12 Kenny B, DeVinney R, Stein M, et al. Enteropathogenic E coli [EPEC] transfers its receptor for intimate adherence into mammalian cells. Cell 1997;91:511-20.

13 Wolff C, Nisan I, Hanski E, et al. Protein translocation into epithelial cells by infecting enteropathogenic Escherichia coli. Mol Microbiol 1998;28:14355 .

14 Donnenberg MS, Kaper JB. Enteropathogenic Escherichia coli. Infect Immun 1992;60:3953-61

15 Hicks S, Frankel G, Kaper JB, et al. Role of intimin and bundle forming pili in enteropathogenic Escherichia coli adhesion to pediatric intestinal tissue in vitro. Infect Immun 1998;66:1570-8.

16 Rosqvist R, Hakansson S, Forsberg A, et al. Functional conservation of the secretion and translocation machinery for virulence proteins of Yersiniae, Salmonellae and Shigellae. EMBO 7 1995;14:4187-95.

17 Cornelis GR, Wolf-Watz H. The Yersinia Yop virulon: a bacterial system for subverting eukaryotic cells. Mol Microbiol 1997;23:861-7.

18 Collazo CM, Galan JE. The invasion-associated type III system of Salmonella typhimurium directs the translocation of Sip proteins into the host cell. Mol Microbiol 1997;24:747-56.

19 Wood MW, Rosqvist R, Mullan PB, et al. SopE, a secreted protein of Salmonella dublin, is translocated into the target eukaryotic cell via a sip-dependent mechanism and promotes bacterial entry. Mol Microbiol 1996;22:327-38.

20 Menard R, Prevost MC, Gounon P, et al. The secreted Ipa complex of Shigella flexneri promotes entry into mammalian cells. Proc Natl Acad Sci USA 1996;93:1254-8.

21 Ginocchio CC, Olmstead SB, Wells CL, et al. Contact with epithelial cells induces the formation of surface appendages on Salmonella typhimurium. Cell 1994;76:717-24. 